\title{
Gill monogeneans of the chub mackerel, Scomber japonicus from Madeiran waters of the Atlantic Ocean, Portugal
}

\author{
G. Costa $^{1 *}$, N. Freitas ${ }^{1}$, T.H. Dellinger ${ }^{1}$ and K. MacKenzie ${ }^{2}$ \\ ${ }^{1}$ Centre for Macaronesian Studies, Campus da Penteada, 9000-390 Funchal, \\ Portugal: ${ }^{2}$ Department of Zoology, University of Aberdeen, Tillydrone \\ Avenue, Aberdeen, AB24 2TZ, Scotland, UK
}

\begin{abstract}
Five species of monogeneans were recovered from the gill filaments of 181 chub mackerel, Scomber japonicus, from the Madeiran waters of the Atlantic Ocean, Portugal, during 2004/2005. The monogenean Pseudokuhnia minor showed the highest prevalence $(98.68 \%$ ) and a mean intensity of 28.23 , followed by Kuhnia scombri (prevalence of $43.71 \%$ and mean intensity of 2.69 ) and K. scombercolias (prevalence of $39.1 \%$ and a mean intensity of 1.81). Kuhnia sprostonae and Grubea cochlear were rare, occurring in only one and five fish hosts respectively. No correlation between fish host length and mean intensity of infection with the three most abundant monogeneans was found. However, significant differences in prevalence and abundance were found in relation to date of sampling for P. minor, and all parasites were aggregated in their distribution.
\end{abstract}

\section{Introduction}

The chub mackerel, Scomber japonicus Houttuyn (Scombridae), a commercially important species in the Madeira Economic Exclusive Zone, inhabits the epipelagic regions of the Atlantic, Indian and Pacific Oceans and adjacent seas (Collette, 1986). Research on the morphology, occurrence and infection dynamics of the helminth parasites of this fish species in Madeiran waters (Atlantic Ocean, Portugal), has been conducted since 1999. The results can be used to study the biogeographical patterns of the observed helminths, which in turn can be important to examine the existence of latitudinal gradients in species diversity (Rohde, 1992; Rohde \& Heap, 1998). Other studies on the parasite composition of scombrids have characterized helminths both from the visceral cavity and gills (Rego \& Santos, 1983; Pozdnyakov \& Vasilenko, 1994; Cremonte \& Sardella, 1997). In particular, the characterization of ectoparasite assemblages for species of the genus Scomber was carried out in temperate regions of the North Atlantic (Somdal \& Schram, 1992) and tropical waters of Australia (Hayward et al., 1998). To date, six species of monogeneans (Monogenea: Mazocraeidae) have been described from

*Fax: +351-291766339

E-mail: gcosta@uma.pt the gills of Scomber spp., including the chub mackerel, namely Pseudokuhnia minor Rohde \& Watson, Kuhnia scombri (Kuhn) Sproston, Kuhnia scombercolias Nasir \& Fuentes Zambrano, K. sprostonae Price, Grubea cochlear Diesing, and Grubea australis Rohde. These monogeneans were found in the gills and pseudobranchs of mackerels. The present work analyses the results on the occurrence and infection dynamics of five species of monogenean in Scomber japonicus from Madeiran waters, followed by a comparison of their occurrence in other oceanic regions. The biogeographic patterns of these parasites are also discussed.

\section{Materials and methods}

One hundred and fifty one chub mackerel, S. japonicus, (sample 1) from Madeiran waters, Atlantic Ocean, Portugal, were examined for the occurrence of gill monogeneans. Fish samples ranging in total length from 23 to $40 \mathrm{~cm}$, were obtained from the local fish market of Funchal, from November 2004 to February 2005. Additionally a sample of 30 chub mackerel, ranging in length from 24 up to $35 \mathrm{~cm}$, was purchased in August 2005 (sample 2). Chub mackerel available in Funchal were caught locally, by a purse seining technique called 'ruama'. Fish were dissected one day after capture, measured in centimetres, weighed in grams, and the 
Table 1. Measurements of total body length, clamp and hamuli size for four species of Kuhnia recovered from the gills of the chub mackerel Scomber japonicus from Madeiran waters.

\begin{tabular}{lccr}
\hline Species & Body length $(\mathrm{mm})$ & Clamp size $(\mu \mathrm{m})$ & Hamuli size $(\mu \mathrm{m})$ \\
\hline Pseudokuhnia minor & $1.72 \pm 0.28(n=32)$ & $54(62-42)(n=38)$ & $42(38-60)(n=30)$ \\
Kuhnia scombri & $3.18 \pm 0.73(n=12)$ & $68.7(55-82.5)$ & $81(70-100)$ \\
K. scombercolias & $2.24 \pm 0.27(n=14)$ & $56.3(32.5-70)$ & $40.5(35-45)$ \\
K. sprostonae & 4.46 & 130 & 67.5 \\
\hline
\end{tabular}

gills dissected out and examined for the presence of monogeneans under a Zeiss Stemi 2000 C stereomicroscope, equipped with a Sony digital camera. Monogeneans were counted, fixed in $70 \%$ ethanol, cleared in lactophenol, and mounted in glycerol jelly. Following microscopic examination, measurements of the monogeneans, taken with the aid of an ocular micrometer, are given in millimetres $(\mathrm{mm})$ or micrometres $(\mu \mathrm{m})$ and presented as means \pm standard deviations. Prevalence, intensity and abundance indices were calculated after Bush et al. (1997). Confidence intervals for the prevalence and intensity of infection, aggregation indices $(D),(k)$ and variance to mean ratios $\left(s^{2} / x\right)$, were calculated using the program Quantitative Parasitology (QP 2.0) of Reiczigel \& Rózsa (Rózsa et al., 2000), according to Poulin (1993) and Bush et al. (2001). The significance of the relationship between prevalence and abundance of infection with host length, sex, weight and date of sampling were tested by univariate analysis of variance using SPSS 12.0. Results were considered significant where $P \leq 0.05$.

\section{Results}

The sample of 151 chub mackerel (sample 1) consisted of 89 females and 62 males. The length of female fish ranged from 23 to $38 \mathrm{~cm}(28.54 \pm 2.74, n=89)$ whereas the length of males was $23.5-40.0 \mathrm{~cm}(28.99 \pm 3.11, n=62)$. A total of 2332 monogeneans belonging to five different species were found attached to the gill filaments of the chub mackerel, namely Pseudokuhnia minor (length 1.15-2.26 mm), Kuhnia scombri (length 1.52-4.12 mm), Kuhnia scombercolias (length $1.62-2.64 \mathrm{~mm}$ ), Kuhnia sprostonae (length $4.46 \mathrm{~mm}$ ) and Grubea cochlear (length $10.3 \mathrm{~mm}$ ) (table 1). The most abundant monogenean species was Pseudokuhnia minor $(n=2072)$, followed by Kuhnia scombri $(n=148), K$. scombercolias $(n=106)$, Grubea cochlear $(n=5)$ and $K$. sprostonae $(n=1)$ (table 2$)$.
The highest prevalence, $98.68 \%$, (95\% confidence limits 95.29 to $99.84 \%$ ) was found for P. minor, followed by a prevalence of $43.71 \%$ for K. scombri $(95 \%$ confidence limits 35.66 to $52.01 \%$ ) and K. scombercolias with $39.07 \%$ of fish infected $(95 \%$ confidence limits 31.24 to $47.34 \%$ ) (table 2). Grubea cochlear occurred in only five fish and K. sprostonae in one fish. Pseudokuhnia minor was also the species with the highest mean abundance $(13.72,95 \%$ confidence limits 12.40 to 15.06 ; bootstrap indices: 46, 1945, sample size =151) and mean intensity $(13.91,95 \%$ confidence limits 12.62 to 15.30; bootstrap indices: 54 , 1954, sample size $=149$ ). The mean abundance with $K$. scombri was 0.98 (95\% confidence limits 0.76 to 1.23 ; bootstrap indices: 55 , 1955, sample size $=151$ ) and the mean intensity $2.24(95 \%$ confidence limits 1.89 to 2.64 ; bootstrap indices: 52 , 1952, sample size $=66$ ), while K. scombercolias had a mean abundance of 0.71 (95\% confidence limits 0.54 to 0.89 , bootstrap indices: 56 , 1956, sample size $=151)$ and a mean intensity of $1.81 \quad(95 \%$ confidence limits 1.54 to 2.15; bootstrap indices: 52, 1952; sample size $=59$ ) (table 2). Sample 2 consisted of 30 fish, 13 females and 17 males. The length of female fish ranged from 25.5 to $34.5 \mathrm{~cm}(30.86 \pm 2.74)$ and the length of males ranged from 24.2 to $34.5 \mathrm{~cm}$ $(31.34 \pm 2.94)$. Again the highest prevalence was found for P. minor $(86.7 \%$, 95\% confidence limits 69.27 to $96.25 \%$ ). The prevalence value for $K$. scombri was about the same as in sample $1(43.3 \%, 95 \%$ confidence limits 25.46 to $62.58 \%$ ), whereas the prevalence with K. scombercolias decreased $(13.3 \%, 95 \%$ confidence limits 37.5 to $30.73 \%$ ). With reference to mean intensity and abundance values, an increase was observed in both values for $P$. minor, the mean intensity being $28.23(95 \%$ confidence limits 21.58 to 35.00 , bootstrap indices: 53 ; $1953)$ and the mean abundance 24.47 (95\% confidence limits 18.67 to 31.50 , bootstrap indices: $71 ; 1966)$. The mean intensity and abundance of both $K$. scombri and K. scombercolias were lower and did not differ much

Table 2. Prevalence, intensity and abundance of monogeneans on the gills of 151 chub mackerel Scomber japonicus with body lengths ranging from 23 to $40 \mathrm{~cm}$, examined from November 2004 to February 2005.

\begin{tabular}{lccccc}
\hline Species & $\begin{array}{c}\text { No. infected } \\
\text { fish }\end{array}$ & $\begin{array}{c}\text { Prevalence } \\
(\%)\end{array}$ & $\begin{array}{c}\text { No. of parasites } \\
\text { (range) }\end{array}$ & Mean intensity & Mean abundance \\
\hline Pseudokuhnia minor & 149 & 98.68 & $2072(1-51)$ & 13.91 & 13.72 \\
Kuhnia scombri & 66 & 43.71 & $148(1-7)$ & 2.24 & 0.98 \\
K. scombercolias & 59 & 39.07 & $106(1-6)$ & 1.81 & 0.71 \\
K. sprostonae & 1 & 0.66 & 1 & 1 & 0.007 \\
Grubea cochlear & 5 & 3.31 & $5(1-1)$ & 1 & 0.03 \\
\hline
\end{tabular}


Gill monogeneans of Scomber japonicus from Madeiran waters

Table 3. Prevalence, intensity and abundance of monogeneans on the gills of 30 chub mackerel Scomber japonicus with lengths ranging from 24 to $34.5 \mathrm{~cm}$, examined in August 2005.

\begin{tabular}{lccccc}
\hline Species & $\begin{array}{c}\text { No. infected } \\
\text { fish }\end{array}$ & $\begin{array}{c}\text { Prevalence } \\
(\%)\end{array}$ & $\begin{array}{c}\text { No. of parasites } \\
\text { (range) }\end{array}$ & Mean intensity & Mean abundance \\
\hline Pseudokuhnia minor & 26 & 86.70 & $734(0-62)$ & 28.23 & 24.47 \\
Kuhnia scombri & 13 & 43.3 & $35(0-8)$ & 2.69 & 1.17 \\
K. scombercolias & 4 & 13.30 & $6(0-2)$ & 1.50 & 0.20 \\
\hline
\end{tabular}

from values obtained in sample 1 (mean intensity $=2.69$; mean abundance $=1.17$ for $K$. scombri; mean intensity $=1.50$, mean abundance $=0.20$ for $K$. scombercolias). The total number of $P$. minor was 734, with $35 \mathrm{~K}$. scombri and six specimens of K. scombercolias respectively (table 3 ).

When combining both samples, the prevalence of $K$. scombri and K. scombercolias was found to be independent of host sex, length, weight and date of sampling (univariate ANOVAs). On the other hand for $P$. minor, the date of sampling and to lesser degree fish weight, had a slight significant effect on prevalence which explained $8 \%$ of the variation $(\mathrm{F}=13.58, P=0.000$; $\mathrm{F}=3.945, P=0.049$, univariate ANOVA). The number of parasites found in fish increased markedly from November 2004 up to August 2005 (fig. 1) indicating a seasonal variation for $P$. minor, where a significant correlation was found between sampling date and the abundance of infection $\left(\mathrm{r}^{2}=0.191, \mathrm{~F}=42.16 P=0.001\right)$ (fig. 1 and table 4). The abundance of infection with $P$. minor varied significantly with sampling date and fish weight $(\mathrm{F}=22.32, P=0.000 ; \mathrm{F}=4.319, P=0.039$ respectively). For $K$. scombri males had slightly higher abundances than females $(F=6.715, P=0.010)$. However, the effects of the date of sampling, fish length, weight and sex on the abundance of the parasites could explain only $20 \%$ of the variation. Pairwise comparisons of monogenean intensities resulted in a positive association between $P$. minor and K. scombri $\left(\mathrm{r}_{\mathrm{s}}=0.263\right.$, $P=0.033$ )

Estimates of the aggregation indices, variance to mean ratios $\left(\mathrm{s}^{2} / \mathrm{x}\right)$, the index of discrepancy $(D)$ and the parameter $(k)$ for the three most prevalent species in sample 1 (table 5), suggested that their distribution follows the negative binomial model, with good agreement between observed and expected frequencies of the parasites (chi-square $=2.09, \quad \mathrm{df}=4, \quad k=0.72$ for $K$. scombercolias; chi-square $=5.62, \mathrm{df}=5, k=0.611$ for K. scombri; chi-square $=25.68, \mathrm{df}=19 ; k=2.79$ for $P$. minor). These results demonstrate that parasites have a tendency to be clumped in some of their hosts. Kuhnia scombri and K. scombercolias show few hosts infected and many hosts uninfected or infected with just one parasite. Pseudokuhnia minor occurs with a high intensity of infection and is less aggregated.

In contrast, in sample 2 the observed and expected frequencies of $P$. minor in each abundance class differed significantly meaning that this monogenean was more regularly dispersed (chi-square $=29.505, \mathrm{df}=18$ ). The number of K. scombri and K. scombercolias was low in this sample, therefore the frequency distribution of the parasites was not analysed. The aggregation indices, variance to mean ratios and index of discrepancies are presented in table 5 .

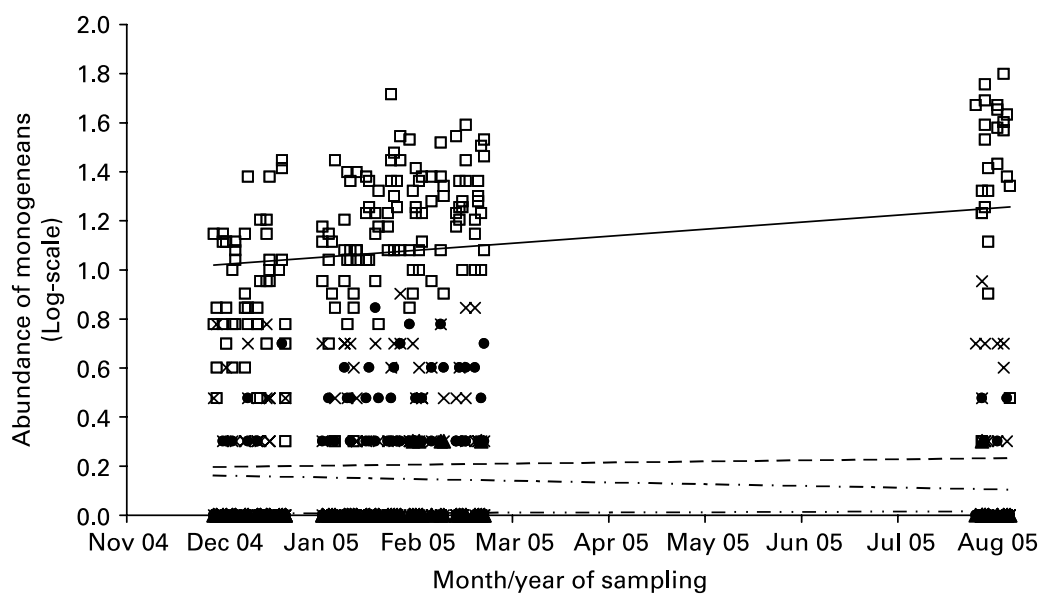

Fig. 1. Variation in the abundance of monogenean infections on the gills of 181 chub mackerel Scomber japonicus from Madeira relative to sampling dates, from November 2004 to August 2005. Pseudokuhnia minor $(\square)$, Kuhnia scombri $(\times)$, Kuhnia scombercolias $(\bullet)$, Grubea

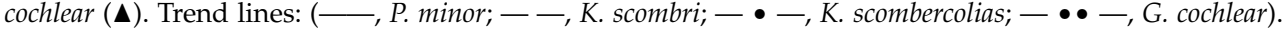


Table 4. Correlation coefficients of four species of monogeneans on the gills of 181 chub mackerel Scomber japonicus from November 2004 to August 2005.

\begin{tabular}{lcrr}
\hline Parasite species & $\mathrm{R}^{2}$ & $\mathrm{~F}$ & \multicolumn{1}{c}{$P$} \\
\hline Pseudokuhnia minor & 0.191 & 42.16 & $<0.001$ \\
Kuhnia scombri & 0.004 & 0.77 & 0.382 \\
K. scombercolias & 0.005 & 0.98 & 0.323 \\
Grubea cochlear & 0.003 & 0.504 & 0.479 \\
\hline
\end{tabular}

\section{Discussion}

\section{Size and number of monogenean species}

Six monogenean species, Pseudokuhnia minor, Kuhnia scombri, K. sprostonae, K. scombercolias, Grubea cochlear and $G$. australis have been reported to date from the gills and pseudobranchs of scombrid fishes (see Rohde \& Watson, 1985a,b; Rohde 1986, 1989a,b). Considerable variability has been found in both body and hamuli length in specimens of the same species collected from different geographical areas and from different hosts (Rohde \& Watson, 1985a,b). Values obtained for total body length and size of the large hamuli for Pseudokuhnia minor in Madeiran samples were close to those obtained for the same fish species from South African Atlantic waters (mean length $=1.72$ and $1.56 \mathrm{~mm}$ respectively; hamuli $42 \mu \mathrm{m}$ mean length and $38-42 \mu \mathrm{m}$ respectively). On the other hand specimens from the Mediterranean and Spanish Atlantic coastal waters, were smaller (mean length $1.12 \mathrm{~mm}$ ) (Rohde \& Watson, 1985a). The total body length of $K$. scombri from Madeira was closer to measurements obtained for South African samples of this species (3.18 and $2.87 \mathrm{~mm}$ respectively), when compared with values for Mediterranean $(1.1-2.4 \mathrm{~mm})$ and south Atlantic waters of Brazil (1.49-3.44 mm) (Rohde \& Watson, 1985b). Kuhnia scombercolias collected from Madeira also showed a larger body size (1.6$2.64 \mathrm{~mm}$ ) and slightly larger hamuli (37.5-67.5 $\mu \mathrm{m})$, while in specimens from Ecuador and Brazil the size of hamuli varied between 36 and $55 \mu \mathrm{m}$. The three species $P$. minor, $K$. scombri and K. scombercolias recovered from Madeiran waters, in summary, are more closely related to South African specimens than to those from Mediterranean and

Table 5. Aggregation indices, variance to mean ratio $\left(s^{2} / x\right)$, index of discrepancy $(D)$ and parameter $(k)$ for the monogeneans Pseudokuhnia minor, Kuhnia scombri and $K$. scombercolias on the gills of 181 chub mackerel Scomber japonicus.

\begin{tabular}{lccc}
\hline & $\begin{array}{c}\text { Pseudokuhnia } \\
\text { minor }\end{array}$ & $\begin{array}{c}\text { Kuhnia } \\
\text { scombri }\end{array}$ & K. scombercolias \\
\hline & $\mathrm{W} / \mathrm{S}$ & $\mathrm{W} / \mathrm{S}$ & $\mathrm{W} / \mathrm{S}$ \\
$\mathrm{s}^{2} / \mathrm{x}$ & $5.653 / 14.16$ & $2.786 / 3.14$ & $0.347 / 1.52$ \\
$k$ & $2.305 /-$ & $0.61 /-$ & $0.711 /-$ \\
$D$ & $1.930 / 0.413$ & $0.72 / 0.71$ & $0.729 /-$ \\
\hline
\end{tabular}

W/S: Winter/summer values.

(-) data not calculated by QP2.0 as frequency distribution of the parasites was not a negative binomial. south-western Atlantic waters, in terms of body length and hamuli size, thus confirming the existence of geographical variation in these parameters.

\section{Prevalence, abundance and intensity of infection}

The most common monogenean species found on the gills of S. japonicus was $P$. minor reaching a maximum prevalence of $98.7 \% \quad(n=151)$. Kuhnia scombri and K. scombercolias also showed relatively high prevalences (43.7 and $39.1 \%$ respectively in sample 1), whereas Grubea cochlear and K. sprostonae were rarely observed (see table 2). The prevalence of K. scombri in other regions of the Atlantic differed considerably, with high values being obtained for the Northeast Atlantic (60$75 \%$ in S. scombrus; Somdal \& Schram, 1992) and off continental Portugal (73.9\% in S. japonicus; Rego, 1985). Contrasting with those high prevalences, only $1.1 \%$ of chub mackerel from Argentinean waters were infected with K. scombri (Cremonte \& Sardella, 1997), 11\% in Brazilian waters (Alves et al., 2003) and 6.6\% in North Pacific waters (Pozdnyakov \& Vasilenko, 1994). These data suggest that this parasite is better adapted to colder temperate waters of the North Atlantic, with Madeira serving as an intermediate region between the colder temperate waters of the North Atlantic and the south Atlantic waters. Of course there are other factors that can mask the differences in prevalence, as for example fish size, although in the present study no correlation between prevalence and fish size was observed. Furthermore, the lengths of chub mackerel examined by Alves et al. (2003) were similar to those examined in Madeira $(20-32 \mathrm{~cm})$. Likewise, the mean length of fish collected from the Skagerrak (North Atlantic) was $30 \mathrm{~cm}$, and prevalence with K. scombri ranged from 76 to $100 \%$ (Somdal \& Schram, 1992). Kuhnia sprostonae which, according to Rohde \& Watson (1985b), is characterized by having a wide geographical distribution, encompassing Pacific waters of Australia, south Atlantic waters of Brazil, coastal waters of Ecuador and the North Sea, was not recovered by Alves et al. (2003) in coastal waters of Brazil, nor from Argentinean waters by Cremonte \& Sardella (1997). Although present in Madeira, this species was extremely rare (present work). On the other hand $K$. scombercolias, which is morphologically similar to K. sprostonae, but with a smaller total body and hamuli length (see Rohde \& Watson, 1985b; Rohde, 1989b), was a relatively frequent species in Madeira (39.1\%) and in the South Atlantic waters of Brazil (46\%, Alves et al., 2003). This monogenean was not recovered from North Atlantic and Argentinean waters. It may be better adapted to warmer waters, being replaced in colder waters by $K$. sprostonae (found in Helgoland, Plymouth, Madeira, southern Australia; while K. scombercolias found in Ecuador, northern New South Wales, Australia, Perth, Western Australia, São Paulo, Brazil and Madeira). Pseudokuhnia minor, the monogenean with the highest prevalence, intensity and abundance in Madeiran waters (present work) was surprisingly not found by previous authors in Atlantic waters off Portugal (Rego, 1985; Rego et al., 1985) and the southwestern Atlantic (Cremonte \& Sardella, 1997; 
Alves et al., 2003). Nevertheless Rohde \& Watson (1985a) studied this monogenean from South African Atlantic waters, Mediterranean and Atlantic waters of Spain, although they did not consider prevalence and intensity. Therefore it is not possible to compare the frequency of occurrence of this monogenean in different geographical regions where it is present, in order to reach more accurate conclusions about the links of those regions and the distribution of this parasite. Apparently P. minor has a more restricted distribution, with preference for warmer waters (Madeira, present work; New South Wales in Hayward et al., 1998). Finally, Grubea cochlear was rare in both $S$. japonicus and $S$. scombrus, with low prevalences ranging from $3.3 \%$ in Madeira, $6 \%$ and $18 \%$ in Brazilian waters (Rego \& Santos, 1983; Alves et al., 2003), while it occurred in S. scombrus with a prevalence of $2.5 \%$ in Portuguese waters (Rego et al., 1985) and $3.4 \%$ in the Mediterranean (Parukhin et al., 1971). Grubea cochlear differs significantly from the other species by its larger size (up to $10 \mathrm{~mm}$ in length). The low number of individuals of G. cochlear both in the present study (five individuals) and elsewhere (see Rohde, 1986) do not allow conclusive statements about the geographical variation of the species, although the species has been recovered from $S$. scombrus and $S$. japonicus from the Atlantic Ocean, Mediterranean and Indo-Pacific waters (Rego \& Santos, 1983; Rohde, 1986; Somdal \& Schram, 1992; Alves et al., 2003).

The mean abundance of $K$. scombri was higher in Madeiran waters $(0.98-1.17)$ and at the austral region (0.14-2.25) (Rohde \& Watson, 1985b) whereas in Brazil and Argentinean waters lower values were obtained (0.2 and 0.01 respectively) (Cremonte \& Sardella, 1997; Alves et al., 2003). The mean abundance of $K$. scombercolias was higher in Brazil (3.7) followed by Madeiran waters $(0.20-0.71)$ and the austral region (0.39-1.20) (Alves et al., 2003; present work). The mean abundance of $P$. minor reached 13.72-24.47 in Madeiran waters, and from 1.29 to 6.13 at the austral region. Taking into account that $P$. minor is much smaller than K. scombri and K. scombercolias, its high intensities could also mean that this species adopted a strategy of closeness to other members of the species, for defence purposes or cooperative feeding (see Bush et al., 2001). An increase in parasite numbers for $P$. minor from November to August observed in Madeiran waters, may be due to parasite reproduction occurring on the fish host when the water temperature rises. However, this assumption would need an experimental study in order to fully comprehend the life cycle of this monogenean.

In a study of the monogenean Gyrodactylus turnbulli of guppies, Poecilia reticulata, Scott (1987) concluded that parasites became more aggregated as their numbers increased, due to direct reproduction of parasites on individual fish. Furthermore, according to this author, the best indicator of the degree of aggregation is the $s^{2} / x$ ratio. In our case this ratio was higher for $P$. minor and increased in the summer (14.16, see table 5). For K. scombri, relatively high values of the $s^{2} / x$ ratio were obtained (see table 5) indicating that at least for these two species, the parasites were aggregated.
The prevalence and abundance of the four monogeneans, Pseudokuhnia minor, K. scombri, K. scombercolias and $K$. sprostonae from the scombrid Scomber australasicus in New South Wales showed similar trends to values obtained at Madeira (Hayward et al., 1998). Consequently, for fish of the same length range, the highest prevalence and intensity was found for P. minor $(58.7-78.2 \%$; $1.56-$ 6.13), followed by K. scombercolias (38.1-59\%; 0.87-1.15), K. scombri (34.4-74.5\%; 0.49-2.25) and K. sprostonae with the lowest values $(1.6-5.5 \% ; 0.03-0.05)$. A positive association found in the intensities of $P$. minor and $K$. scombri in the present work may have several explanations (Hayward et al., 1998). One possible explanation could be an increase in susceptibility to infection, once one of the parasites settles on the host gills or one species could establish the microhabitat for the second species.

The occurrence of monogeneans in Scomber japonicus at Madeira, with the disparity of degrees of prevalence and intensity, may lead to the conclusion that Madeiran waters represent an interesting mixing point for the monogeneans, with species more frequent in colder waters, such as K. sprostonae, species characteristic of warmer waters, such as K. scombercolias, and species with wide geographical distributions such as K. scombri. Pseudokuhnia minor, which seems to be more host-specific, having been recorded from S. japonicus and S. australasicus only, apparently has a preference for warmer waters, with higher intensities occurring when the water temperature rises (present study). Further studies on the influence of temperature in the abundance of $P$. minor are in progress in order to test this assumption. Its presence in South African and Madeiran samples in $S$. japonicus may indicate a relationship between host populations in these areas, in contrast to its absence from Brazilian populations.

\section{Acknowledgements}

The authors would like to express their gratitude to the Portuguese Foundation of Science and Technology for financial support, through the POCTI/Plurianual Program and to two anonymous reviewers.

\section{References}

Alves, D.R., Luque, J.L. \& Abdallah, V.D. (2003) Metazoan parasites of chub mackerel, Scomber japonicus Houttuyn (Osteichthyes: Scombridae), from the coastal zone of the state of Rio de Janeiro, Brazil. Revista Brasileira Parasitologia Veterinária 12, 164-170.

Bush, A.O., Lafferty, K.D., Lotz, J.M. \& Shostak, A.W. (1997) Parasitology meets ecology on its own terms: Margolis et al. revisited. Journal of Parasitology 83, 575-583.

Bush, A.O., Fernández, J.C., Esch, G.W. \& Seed, J.R. (2001) Parasitism, the diversity and ecology of animal parasites. 566 pp. Cambridge, Cambridge University Press.

Collette, B.B. (1986) Scombridae. pp. 981-997 in Whitehead, P.J.P., Bauchot, M.L., Hureau, J.C., Nielsen, J. \& 
Tortonese, E. (Eds) Fishes of the north-eastern Atlantic and Mediterranean. UK, Unesco.

Cremonte, F. \& Sardella, N.H. (1997) The parasite fauna of Scomber japonicus Houttuyn, 1782 (Pisces: Scombridae) in two zones of the Argentine Sea. Fisheries Research 31, 1-9.

Hayward, C.J., Perera, L.K.M. \& Rohde, K. (1998) Assemblages of ectoparasites of a pelagic fish, slimy mackerel (Scomber australasicus) from south-eastern Australia. International Journal for Parasitology 28, 263-273.

Parukhin, A.M., Naidenova, V.M. \& Nikolaeva, V.M. (1971) On the parasite fauna of fish of the western part of the Mediterranean. pp. 64-87 in Vodjanichky, V.A. (Ed.) Expeditionary investigations in the Mediterranean Sea in May-July 1970 (66th voyage of the RV Ak. A. Kovatevsky). Kiev, Izdatelstvo Naukova Dumka (in Russian).

Poulin, R. (1993) The disparity between observed and uniform distributions: a new look at parasite aggregation. International Journal for Parasitology 23, 937-944.

Pozdnyakov, S.E. \& Vasilenko, A.V. (1994) Distribution, migration and the helminth fauna of the Japanese mackerel, Scomber japonicus, in the northwestern Pacific Ocean. Journal of Ichthyology 34, 74-91.

Rego, A.A. (1985) Identificação de helmintes de peixes da costa continental portuguesa. Garcia da Orta, Ser. Zoologia 12, 113-116.

Rego, A.A. \& Santos, C.P. (1983) Helmintofauna de cavalas, Scomber japonicus Houtt, do Rio de Janeiro. Memórias Instituto Oswaldo Cruz 78, 443-448.

Rego, A.A., Carvalho-Varela, M., Mendonça, M.M. \& Afonso-Roque, M.M. (1985) Helmintofauna da sarda (Scomber scombrus L.) peixe da costa continental portuguesa. Memórias do Instituto Oswaldo Cruz 80, 97-100.

Rohde, K. (1986) Grubea australis n. sp. (Monogenea, Polyopisthocotylea) from Scomber australasicus in southeastern Australia, and Grubea cochlear Diesing, 1858 from S. scombrus and S. japonicus in the
Mediterranean and western Atlantic. Systematic Parasitology 9, 29-38.

Rohde, K. (1989a) Gill monogenea of Rastrelliger spp. (Scombridae). Systematic Parasitology 14, 79-91.

Rohde, K. (1989b) Kuhnia sprostonae Price, 1961 and K. scombercolias Nasir \& Fuentes Zambrano, 1983 (Monogenea: Mazocraeidae) and their microhabitats on the gills of Scomber australasicus (Teleostei: Scombridae), and the geographical distribution of seven species of gill monogenea of Scomber spp. Systematic Parasitology 14, 93-100.

Rohde, K. (1992) Latitudinal gradients in species diversity: the search for the primary cause. Oikos 65, 514-527.

Rohde, K. \& Heap, M. (1998) Latitudinal differences in species and community richness and in community structure of metazoan endo- and ectoparasites of marine teleost fish. International Journal for Parasitology 28, 461-474.

Rohde, K. \& Watson, N. (1985a) Morphology and geographical variation of Pseudokuhnia minor n.g., n. comb. (Monogenea: Polyopisthocotylea). International Journal for Parasitology 15, 557-567.

Rohde, K. \& Watson, N. (1985b) Morphology, microhabitats and geographical variation of Kuhnia spp. (Monogenea: Polyopisthocotylea). International Journal for Parasitology 15, 569-586.

Rózsa, L., Reiczigel, J. \& Majoros, G. (2000) Quantifying parasites in samples of hosts. Journal of Parasitology 86, 228-232.

Scott, M.E. (1987) Temporal changes in aggregation: a laboratory study. Parasitology 94, 583-595.

Somdal, O. \& Schram, T.A. (1992) Ectoparasites on the Northeast Atlantic mackerel (Scomber scombrus L.) from western and North Sea stocks. Sarsia 77, 19-31.

(Accepted 14 June 2006) (C) 2007 Cambridge University Press 